\title{
Responses of primary visual cortical neurons to natural movies in anesthetized cat Shih-Cheng Yen*1, Jonathan Baker ${ }^{2}$, Jean-Philippe Lachaux ${ }^{3}$ and Charles M Gray²
}

\author{
Address: ${ }^{1}$ Department of Electrical and Computer Engineering, National University of Singapore, Singapore 117576, Singapore, ${ }^{2}$ Center for \\ Computational Biology, Montana State University, Bozeman, Montana 59717, USA and INSSERM U821, Lyon F-69500, France \\ Email: Shih-Cheng Yen* - shihcheng@alumni.upenn.edu \\ * Corresponding author
}

from Seventeenth Annual Computational Neuroscience Meeting: CNS*2008

Portland, OR, USA. 19-24 July 2008

Published: II July 2008

BMC Neuroscience 2008, 9(SuppI I):PI25 doi:I0.II86/I47I-2202-9-SI-PI25

This abstract is available from: http://www.biomedcentral.com/I47I-2202/9/SI/PI25

(c) 2008 Yen et al; licensee BioMed Central Ltd.

We previously reported a high degree of response heterogeneity in neighboring primary visual cortical neurons of the anesthetized cat when presented with natural movies [1]. In this study, we investigated the response properties of those neurons.

First, we computed the inter-spike interval (ISI) histograms of the 88 cells in our database. Twenty-eight cells were excluded from further analysis due to sparse interval data. A large fraction of the remaining 60 cells exhibited a predominance of short ISIs. The maximum value in the histogram in 39 cells was below $2 \mathrm{~ms}$, and was below $4 \mathrm{~ms}$ for all but 8 cells. In addition, by inspecting the joint interval histogram of each spike interval versus the subsequent interval, we found these short intervals to be mainly due to spike bursts rather than spike doublets.

Next, we characterized the firing rate distributions of each neuron by computing the average firing rate for each movie frame across 100 repetitions of the movie. The resulting distributions were fit with both exponential $(\mathrm{y}=$ $\left.a^{*} \exp \left(b^{*} x\right)\right)$ and power $\left(y=a^{*} x^{\wedge} b\right)$ functions. Using goodness-of-fit to bootstrap the data (1000 resamples), we found 43 of the cells were significantly better characterized by a power function ( $p<0.05$ and R-square $>0.75$ ) while 13 of the cells were best fit by an exponential function. The remaining cells were not well fit by either function.
Finally, we investigated the spike-count and spike-time variability across repetitions within each movie frame. In order to quantify the effect of the relative refractory period on response variability, we compared the variability of the cells to 1000 surrogates generated using the method described in a previous study [2]. The only modification was that after computing the free-firing rate at a resolution of $0.2 \mathrm{~ms}$, we averaged the free-firing rate across different time windows to simulate Poisson processes with rates changing at different speeds. With the rate changing every $40 \mathrm{~ms}$, we found that only $1.2 \%$ of the windows with an average of at least 1 spike per window exhibited Fano Factors that were lower than $95 \%$ of the surrogates. This percentage remained invariant with faster rate changes in the surrogates. Using an entropy measure to quantify spiketime variability, we found $49.3 \%$ of the aforementioned windows exhibiting lower variability than $95 \%$ of the surrogates with rates changing every $40 \mathrm{~ms}$. This percentage decreased to $44.8 \%, 40.4 \%$, and $37.28 \%$, when the rates changed every 20,10 , and 5 ms respectively.

Our results indicate that when stimulated with natural movies, striate cortical neurons exhibit responses that are better described using power-law instead of exponential distributions [3]. In addition, we found spike-time variability that was substantially lower than that predicted from time-varying Poisson processes with relative refractory periods. 


\section{Acknowledgements}

This work was supported by grants from the National Eye Institute and the Singapore Ministry of Education AcRF Tier I Fund (R263000355 I I2, R263000355I33).

\section{References}

I. Yen S-C, Baker J, Gray CM: Heterogeneity in the responses of adjacent neurons to natural stimuli in cat striate cortex. J Neurophysiol 2007, 97:|326-I34|.

2. Berry MJ, Meister M: Refractoriness and neural precision. J Neurosci 1998, 18(6):2200-22II.

3. Baddeley R, Abbott LF, Booth MC, Sengpiel F, Freeman T, Wakeman $E A$, Rolls ET: Responses of neurons in primary and inferior temporal visual cortices to natural scenes. Proc R Soc Lond B Biol Sci 1997, 264(1389): 1775-1783.

Publish with Bio Med Central and every scientist can read your work free of charge

"BioMed Central will be the most significant development for disseminating the results of biomedical research in our lifetime. "

Sir Paul Nurse, Cancer Research UK

Your research papers will be:

- available free of charge to the entire biomedical community

- peer reviewed and published immediately upon acceptance

- cited in PubMed and archived on PubMed Central

- yours - you keep the copyright

Submit your manuscript here:

http://www.biomedcentral.com/info/publishing_adv.asp 